\title{
Enditint
}

\section{Changes to OECD Commentary may affect its credibility}

Marcel Romyn, Moret, Ernst \& Young, Rotterdam

Earlier this year the Organisation for Economic Co-operation and Development published a report called 'Attribution of Income to Permanent Establishments'. The report of the OECD Committee on Fiscal Affairs examines the circumstances under which income is to be attributed to a permanent establishment for purposes of an income tax treaty, where goods, services, or intangibles are transferred between the permanent establishment and the home office or another permanent establishment. The report recommended changes in the Commentary to the OECD Model Tax Convention, which were subsequently incorporated in the Commentary's 1994 update.

The report intends to clarify the application of the rules concerning the determination of the income of permanent establishments. Rather than giving a comprehensive, clear and consistent rule to what extent the deemed independence of a permanent establishment applies, the report focuses on three specific questions: recognition of profits, recognition of internal agreements and pricing of internal transactions. Repeatedly - and erroneously - the report identifies these issues as issues of international economic double taxation, rather than juridical double taxation.

The Commentary to the OECD Model Tax Convention is considered authoritative because it reflects the consensus of representatives of OECD Member States. In some countries the Commentary is even used by tax courts in interpreting provisions of actual treaties identical to the provisions of the model. The Commentary itself, somewhat pretentiously, observes that changes and additions to it should normally be applicable to the interpretation of conventions even concluded before the adoption of such changes. Pretentiously, because although the Committee on Fiscal Affairs may consist of experts, these experts are still merely government officials without the legislative powers required to change the meaning of pre-existing agreements.

This is particularly striking where the Commentary reverses a position previously taken and such a change of heart is not reflected in the text of the model itself. An example is the allocation of interest expenses to a branch. The report is unhappy about the direct and indirect apportionment of actual debt charges suggested in the Commentary to Article 7 before its 1994 update. Instead, maintaining the general ban on deductions for internal debts and receivables, it prefers to take into account 'a capital structure appropriate to both the organization and the functions performed' (this is now incorporated in OC 7/18.3). The report states that if a permanent establishment were undercapitalized, it would be up to the head office country to avoid any risk of double taxation by allowing a deduction for the part of the interest payments that the permanent establishment had not been able to deduct from its taxable income. If a permanent establishment were overcapitalized, it should be entitled to deduct a fair amount for deemed interest and such remuneration of the financing function would be for the head office a compensation for not investing the amount in long-term loans.

While this approach certainly appears reasonable, the results may not be very predictable. Whether a permanent establishment is under- or overcapitalized, will, according to the report, absent mutual agreement, depend on the rules and practice of the host country, which may not always be definite. But the important point here is that it is not easy to see how this approach is at all compatible with the wording of paragraph 3 of Article 7 of the Model Tax Convention. It may adversely affect the credibility of the Commentary.

Also the 'consensus' underlying the Commentary's perceived authority may, occasionally, only be achieved by taking ambivalent or even inconsistent positions. An example is the report's discussion of the significance of 'contracts' between permanent establishment and home office. The report mentions that such contracts are not generally recognized in other cases than transactions involving goods and services that are essentially the same as those supplied to third parties. The reason for this, the report points out, is the fear among 
Member States that full application of the 'arm's length principle' will result in the creation of artificial profits or losses to the extent that taxable income of an enterprise as a whole would differ from that that would be calculated if the enterprise was conducting business from one point. The report then calls this fear both 'unjustified' and 'not unfounded' in one and the same paragraph, presumably making everybody happy.

The report advocates the approach where enterprises frame their 'internal agreements' in the light of the functions really performed by the different 'parties' (presumably: parts of the enterprise), provided this is disclosed in a consistent manner both in the head office and permanent establishment accounts (OC 7/12.1). On the other hand it rejects as an example, an 'internal agreement' allotting to a permanent sales establishment the role of principal (accepting all the risks and entitled to all the profits from the activity) when in fact the permanent establishment concerned was nothing more than an intermediary or agent (incurring limited risks and receiving a limited share of the resulting income) (emphasis added). The report fails to explain how to determine how risk is in fact distributed among different part of a single enterprise and how one can be an agent of himself.

Surprisingly, the report's recommendation with respect to the 'contract' issue is that Member Countries agree as to when the direct method and when the indirect method should be used and that Member Countries base their computations on the national or functional currency used by the enterprise. There is no 'contract issue' to begin with when the indirect method to apportion profits is used, but this method is clearly not the method of choice of Article 7 of the Model Convention.

If goods are transferred from a permanent establishment to its home office, the question arises as to whether the country where the permanent establishment is situated may take its profits into account, even though the enterprise as a whole has not realized any. The committee thinks such 'outward transfer' countries taxing permanent establishments cannot be expected to defer levying tax on transfers of goods until a profit has actually been made, since in their capacity as hosts to foreign enterprises' permanent establishments they obviously cannot follow what happens to a good once it has been transferred and is no longer in their jurisdiction.

The Committee apparently hasn't much confidence in the exchange of information procedures of tax treaties. The Report appreciates that in the case of a transfer of fixed assets or, on the termination of a permanent establishment, the transfer of its entire operating stock, the time lag between the taxable transfer and the actual realization of profits may be substantial. Nonetheless, it considers it unrealistic to expect that the outward country would unilaterally defer levying tax. It does consider it realistic, where there is a serious risk of double taxation, for the head office country to seek a bilateral solution with the outward country (OC 7/15.1). The Committee apparently has a lot of confidence in mutual agreement procedures of tax treaties; the report generally puts a lot of faith in bilateral solutions.

The report pays considerable attention to the transfer from or to bank branches of loans that have depreciated in value and considers whether such transfers should be recognized at all. The report would deny recognition-and not merely adjust the price taken into account - where a transfer would not have taken place between independent enterprises and assumes that this is the case where it is undertaken solely for tax purposes with the aim of maximizing the tax relief available to the bank. This assumption in its generality seems to be in error. In a country where losses are recognized for tax purposes only when realized, a bank may very well decide to sell a loan that has depreciated in value to a third party solely to take the tax benefit of the loss. In fact the report itself recognizes this (OC 7/15.2 and 15.3).

The report notes that the 'arm's length principle' is generally accepted in case of a final transfer of goods, but that with respect to central administrative services, the use of intangibles, temporary assignment of equipment and the transfer of financial assets the general rule is the allocation of actual costs, i.e. profits are not recognized on internal transfers. In case of outward transfers from a permanent establishment of a foreign enterprise, however, application of the arm's length principle is generally required. Consequently a discrepancy exists between accounting for outward transfers and inward transfers and taxpayers may be taxed on profits not actually realized.

The report notes that the problem derives in part from the need to reconcile paragraphs 2 and 3 of Article 7 of the Model Convention. The former requires that prices between the permanent establishment and the head office be charged on an arm's length basis, generally yielding the transferor a profit, while the latter provides that the deduction for expenses incurred for the purpose of the permanent establishment should be the actual costs of those expenses, i.e. without adding any profit. The report maintains that there is no difference in principle between the two paragraphs, but does not clearly explain why (OC 7/17). The report regards the costs of the creation of intangibles such as technology and trademarks as 
attributable to all parts of an enterprise which will make use of them and advocates an allocation of actual costs as they incur, without any mark-up or royalty (OC 7/17.4).

The report does not discuss why the allocation of costs of goods should differ from the allocation of the cost for the use of capital or intangibles. A discussion of the 'functional analysis' theory is also missing. Other issues that are not addressed include the question of how expenses incurred with respect to a permanent establishment before it actually exists and profits accruing from a permanent establishment after it is terminated should be treated and to what extent a taxpayer has the option to allocate assets to a permanent establishment (as the German Bundesfinanzhof has decided). 